Article

\title{
Long-Term Storage Credits: Analyzing Market-Based Transactions to Achieve Arizona Water Policy Objectives
}

\author{
Rebecca F. A. Bernat ${ }^{1, *}$, Sharon B. Megdal ${ }^{2}$ and Susanna Eden ${ }^{3}$ \\ 1 Department of Environmental Science, College of Agriculture and Life Science, The University of Arizona, \\ Tucson, AZ 85721, USA \\ 2 Department of Environmental Science and Water Resources Research Center, College of Agriculture and Life \\ Science, The University of Arizona, Tucson, AZ 85721, USA; smegdal@email.arizona.edu \\ 3 Water Resources Research Center, College of Agriculture and Life Science, The University of Arizona, \\ Tucson, AZ 85721, USA; seden@email.arizona.edu \\ * Correspondence: rebeccabernat@email.arizona.edu; Tel.: +1-520-990-6583
}

Received: 31 December 2019; Accepted: 11 February 2020; Published: 19 February 2020

\begin{abstract}
The state of Arizona has created a unique water management tool in response to water scarcity and population growth. In 1994, Arizona's state legislature authorized the creation of long-term storage credits (LTSCs) through aquifer recharge with Colorado River water or effluent. LTSC represent a quantity of water the owner is entitled to recover and use once the water has remained underground for a full calendar year. Owners may also sell their LTSCs to others by a simple credit account transfer. LTSCs have emerged as a tool for water users to achieve compliance with groundwater regulations in the most populated areas of the state, such as the cities of Phoenix and Tucson. Using data collected and maintained by the state's water resources regulator, this study examines sales of LTSCs to reveal patterns of market-based transactions. Analysis of 23 years of public records shows several trends: (1) LTSC transactions have been increasing since 2003; (2) municipal water providers and investment firms have been active participants in LTSC transactions; (3) the greatest transaction volumes involve governmental entities established by state law with groundwater recharge and replenishment obligations. This analysis reveals how LTSCs have contributed to achieving water policy goals in Central Arizona and suggests how the LTSC system can be used to improve water use efficiency through voluntary redistribution in other water scarce regions.
\end{abstract}

Keywords: market-based transactions; long-term storage credits; water policy; water management; Arizona; recharge

\section{Introduction}

Arizona is a semi-arid state in the southwestern United States that has growing water demands, significant groundwater overdraft, and surface water supplies with diminishing reliability [1]. Climate change also contributes to water scarcity, through rising temperatures and more variable rainfall [2]. Limited water availability creates competition among water users; consequently, water markets can be expected to emerge [3]. This is a situation faced by many other regions worldwide.

For 25 years, many entities in the state of Arizona have been securing water for future use through the creation or purchase of long-term storage credits (LTSCs). Creation of LTSCs through underground storage of Colorado River water or effluent allows LTSC initiators or subsequent purchasers to recover water in times of need, subject to specific regulations. One LTSC is equal to 1 acre-foot of water or 1233.4 cubic meters $\left(\mathrm{m}^{3}\right)$. When they are bought or sold, LTSCs become part of market-based water transactions. Those LTSC transactions are part of Arizona's current water management system. 
This article describes the contribution of LTSCs to meeting the state's policy goals in the most populated areas of Central Arizona. The accrual of and ability to sell LTSCs provide flexibility in the utilization of the stored water in a manner that supports economic growth.

The analysis of LTSC market-based transactions reveals a clear pattern of trades among investment firms, municipal water providers, and governmental entities that assists these entities in meeting their water management responsibilities. Tools similar to LTSCs may be adapted to help accomplish essential water redistribution elsewhere and ameliorate scarcity through improved water use efficiency.

\section{Background}

\subsection{Groundwater Management Act and Central Arizona Project}

Arizona water users rely on a variety of sources. In 2017, groundwater and Colorado River water met, respectively $40 \%$ and $36 \%$ of Arizona's annual water demands, while in-state rivers (21\%), and reclaimed water (3\%) met the remainder [4]. The Colorado River is governed by the "Law of the River," a system of laws, Congressional actions, court cases, contracts and agreements among the Colorado River basin states and the Republic of Mexico, dating back to the early twentieth century [5-7]. In 1922, the Colorado River Compact divided the Colorado River Basin into the Upper Colorado River Basin-Wyoming, Colorado, Utah, New Mexico, and a small part of Arizona-and the Lower Colorado River Basin-California, Arizona, and Nevada. This Compact allocated half (more than 9 billion $\mathrm{m}^{3}$ ) of the annual estimated flow on the Colorado River to each basin. In 1928, the Boulder Canyon Act allocated more than 5.4 billion $\mathrm{m}^{3}$ of the Colorado River water to California, more than 3.4 billion $\mathrm{m}^{3}$ to Arizona, and 370 million $\mathrm{m}^{3}$ to Nevada. Around $46 \%$ of Arizona's allocation of the Colorado River water is used by mainstream users, like farmers and irrigation districts in the Yuma area and four tribes [8]. About $54 \%$ of the Colorado River water has been delivered through the Central Arizona Project (CAP), a 336-mile canal system completed in 1992 that transports water from the Colorado River on the western boundary of Arizona uphill to Central Arizona. The Central Arizona Water Conservation District (CAWCD), a governmental subdivision of Arizona encompassing Maricopa, Pima and Pinal counties, operates the CAP canal delivery system and sets charges for the water delivered through the canal. Generally, Colorado River water delivered via the CAP canal is referred to as CAP water.

In 1980, the Groundwater Management Act created Active Management Areas (AMAs), where groundwater use is regulated by the Arizona Department of Water Resources (ADWR). The boundaries of the five AMAs-Phoenix, Pinal, Prescott, Santa Cruz, and Tucson-are determined largely by hydrologic considerations (Figure 1). In 2016, the AMAs included 82\% of Arizona's more than seven million residents $[9,10]$. This article focuses on the three AMAs that overlap the service area of the CAP and that have entered into market-based transactions of LTSCs: Phoenix, Pinal, and Tucson. These AMAs have four principal water sectors: municipal, industrial, agricultural, and Indian. According to ADWR, most of the 2016 water demand in the Phoenix and Tucson AMAs came from the municipal and agricultural sectors. Of the Phoenix AMA's total water demand of 2.8 billion $\mathrm{m}^{3}, 48 \%$ was municipal and 31\% was agricultural, and the Tucson AMAs sectoral percentages were similar ( $48 \%$ and $32 \%$ respectively) out of 387 million $\mathrm{m}^{3}$ [11,12]. The agricultural sector alone used $80 \%$ of 1.3 billion $\mathrm{m}^{3}$ in the Pinal AMA [13]. In the three AMAs combined, the Indian sector, a good portion of which is agricultural, accounted for $12 \%$, and the industrial sector $7.1 \%$, of the water demand [11-13]. 


\section{Arizona Active Management Areas (AMA's)}

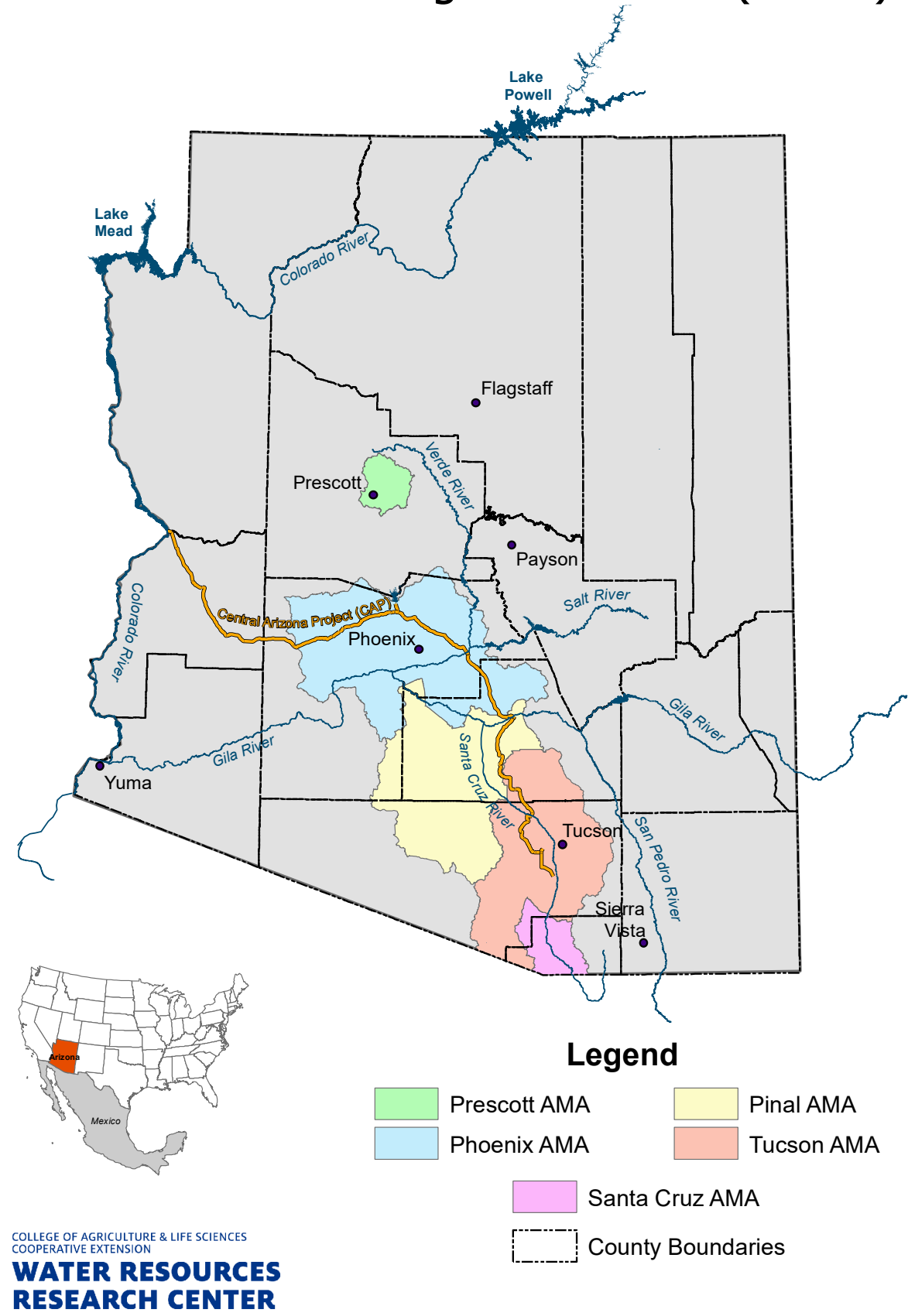

Figure 1. Map of Arizona showing the Active Management Areas and county boundaries.

The Groundwater Management Act also grants groundwater rights to specific users in the AMAs. For example, agricultural sector users were granted groundwater rights (these are referred to as "grandfathered irrigation rights") [14]. These rights may be converted to "type 1 rights" for non-irrigation purposes on the land that had been irrigated and may be conveyed with the land to new owners. Municipal water providers have groundwater rights to provide water for customers in their service area (these are referred to as "service area rights") [15]. Industrial sector users were granted groundwater rights (these are referred to as "type 2 rights") [16], and can apply for groundwater 
withdrawal permits $[17,18]$. Finally, landowners can apply for rights to pump groundwater for non-irrigation uses from exempt wells, which have a capacity of less than $132 \mathrm{~L}$ per minute [19].

\subsection{Assured Water Supply Rules}

Within an AMA, new community developments must demonstrate a 100-year Assured Water Supply (AWS). Approved in 1995, the AWS Rules are the cornerstone of the Groundwater Management Act $[20,21]$. The AWS Rules require the demonstration of physically, legally, and continuously available water supplies for 100 years, financial capability to treat and deliver water that meets water quality standards, consistency with the statutory groundwater management goal of the AMA, and consistency with the periodic management plans required for each AMA [20,21]. The management plans assist in achieving management goals by primarily providing a framework for conservation regulations for the major water sectors [22].

The Phoenix and Tucson AMAs have the same management goal, "safe-yield by 1 January 2025, or such earlier date as may be determined by the [ADWR] director" [23]. The term "safe-yield" means "a groundwater management goal which attempts to achieve and thereafter maintain a long-term balance between the annual amount of groundwater withdrawn in an active management area and the annual amount of natural and artificial recharge in the active management area" [24]. "The management goal of the Pinal active management area is to allow development of non-irrigation uses and to preserve existing agricultural economies in the active management area for as long as feasible, consistent with the necessity to preserve future water supplies for non-irrigation uses" [23].

Consistency with the management goal of the AMA, and thus adherence to the AWS Rules, limits the volume of groundwater applicants of an AWS can use. Any groundwater pumped above the limit specified for each AWS designation or certificate is called "excess groundwater". Each year the entity that pumps groundwater pursuant to an AWS designation or certificate reports the quantity of excess groundwater pumped and this quantity must be replenished. Replenishment means that the excess groundwater pumped from an aquifer in an AMA is replaced with the same quantity of renewable water in an aquifer within the same AMA. CAP water and effluent are considered renewable water, unlike groundwater.

Municipal water providers that want to facilitate development in their service areas must apply for a designation of AWS. Designated municipal water providers may use a volume of groundwater consistent with their AMA management goal. Part of this volume is a volume of incidental recharge calculated by multiplying the provider's total water use in the previous year by a factor of $4 \%$ as established by the ADWR [25-27]. In addition, municipal water providers that started providing water before 7 February 1995 in the Phoenix and Tucson AMAs, are granted a groundwater allowance based on their 1994 water supply multiplied by an allocation factor (7.5 in the Phoenix AMA [25], 15 in the Tucson AMA [27]). In the Pinal AMA, municipal water providers that started providing water before 1 October 2007, and filed a designation of AWS by 1 January 2012, are also granted a groundwater allowance. This groundwater allowance is calculated by multiplying a volume of $473 \mathrm{~L}$ per capita per day by the applicant's service area population for 365 days [26]. Although the volume of groundwater to which municipal water providers applying for AWS designation are entitled will not decrease, an increase in water demand will force applicants to seek more renewable supplies.

Real estate developers who are subdividing land into six or more lots not located within the service area of a designated municipal water provider must apply for a certificate of AWS. To get an AWS certificate, a developer's estimated water use must be consistent with the management goal of the AMA. Applicants for a certificate of AWS are granted a groundwater allowance based on the estimated water demand of the subdivision at the time the application multiplied by an allocation factor (4 in the Phoenix [25] and Tucson [27] AMAs, and 10 in the Pinal AMA [26]).

If more groundwater is required by the applicant of a certificate or a designation of AWS, it will be considered excess groundwater and must be replenished. The state legislature created the Central Arizona Groundwater Replenishment District (CAGRD) in 1993 as a mechanism facilitating compliance 
with the consistency of the management goal requirement of the AWS program [28]. Applicants for AWS designation or certification that demonstrate physical groundwater availability to ADWR but do not have access to a renewable water supply have the option to become CAGRD members. Operated by the CAWCD, CAGRD replenishes groundwater on behalf of its members [27]. There are two types of memberships: member lands and member service areas. A member service area is the service area of a water provider that chooses to become a CAGRD member in order to demonstrate consistency with the AMA management goal. The provider will then pay annual membership dues and an annual assessment to the CAGRD based on the volume of excess groundwater delivered to its customers. To obtain an AWS certificate, a developer without access to sufficient renewable water can demonstrate consistency with the AMA management goal by enrolling the development as member land in the CAGRD. The parcel owner, whether the developer or the subsequent homeowner, pays annual membership dues and an annual assessment to the CAGRD based on the volume of excess groundwater the parcel owner uses.

\subsection{The Underground Water Storage, Savings, and Replenishment Act and the Creation of Long-Term Storage Credits}

In 1986, the Arizona Legislature resolved certain issues pertaining to ownership and control of renewable water stored in recharge project with passage of the Groundwater Storage and Recovery Projects Act. This act was revised in 1994 as the Underground Water Storage, Savings and Replenishment Act to authorize the creation of LTSCs. When CAP water or effluent is recharged, ADWR calculates the amount considered recoverable as annual storage and recovery and the amount that can be recovered as LTSCs.

Water can be stored in underground storage facilities (USFs) and groundwater saving facilities (GSFs). A USF is a direct recharge facility in which water enters the aquifer, either through infiltration basins or injection wells, or, in cases that meet specified criteria, through a natural stream channel called managed USF. A GSF is an indirect recharge mechanism by which CAP water or effluent is used in place of groundwater. GSFs save groundwater by leaving water underground that would otherwise have been pumped and used [29]. The entities providing CAP water or effluent used in lieu of groundwater receive LTSCs for the groundwater that was saved.

ADWR implements and enforces three types of permits that are independent of one another and required for recharge and recovery: the storage facility permit, the water storage permit, and the recovery well permit. The storage facility permit allows operation of a recharge facility. If effluent is to be recharged, a storage facility also requires an Aquifer Protection Permit from the Arizona Department of Environmental Quality. The water storage permit establishes the ability to store water at a facility. An entity must have a storage permit to accrue LTSCs. The recovery well permit identifies wells that may be used to recover stored water. With few exceptions, all the water deemed recoverable by ADWR can be recovered if the recovery takes place in the same calendar year as the storage. If the water stored in the aquifer remains after the calendar year, LTSCs are issued, and the amount of LTSCs will not increase or decrease no matter how long the credits are held on an account. In this way, the amount of LTSCs issued can be understood as static over time, unless the physical water is recovered, in which case a LTSC account balance would correspond to such a withdrawal. Ninety-five percent of the CAP water deemed recoverable by ADWR may be recorded as LTSCs. Five percent of the recoverable water must remain in the aquifer as the "cut to the aquifer." Effluent stored at a managed USF on or after 31 January 2019 is also subject the 5\% cut. The objective of this "cut" is to augment Arizona groundwater.

Water that was stored as LTSCs in an AMA may be recovered under certain conditions. A recovery well permit must be granted by ADWR [30] and recovery must either occur within the area of impact of the stored water, or be located in an area experiencing an average annual rate of decline that is less than $1.22 \mathrm{~m}$ per year within the AMA of the stored water [31-33].

Water may also be stored, and LTSCs may also be used for replenishment purposes by a replenishment district (an entity that develops, stores, replenishes or otherwise increases water supplies 
for the benefit of its members) [34]. An amount of "excess groundwater" pumped may be replenished by storing an equal amount of renewable water in the aquifer, or by extinguishing an equal amount of LTSCs on the replenishment district account.

ADWR keeps track of every cubic meter of water stored at a permitted recharge facility pursuant to a water storage permit, which assures that credits are granted only for water reaching the aquifer and that the credit owner has the right to recover, sell, or extinguish the credit.

\section{Framework for Long-Term Storage Credits Market-Based Transactions}

This section proposes a framework for understanding sales of LTSCs as market-based transactions. In general, a market is a platform for transactions in which something of value may be bought and sold. Studies of water markets in the Southwestern U.S. almost exclusively examine the process of and possibilities for trading water rights [35-47]. Thomas Brown [48], David Brookshire et al. [40], and a recent review by Kurt Schwabe et al. [49] analyzed markets for water rights in Arizona, but scholars have not described a market for LTSCs.

Bonnie Colby (p. 1116) [37] defined the term "market" as "a set of transactions taking place continuously over a period of time." According to Colby's definition, a "going" price was a "key market function." Because sellers and buyers are not required to disclose the price of the LTSCs purchased, price information is scarce. Buyers and sellers do not have a clear price reference point. Moreover, at approximately 20 transactions per year, the market for LTSCs has been "thin" by Colby's reckoning. Discussion of successful water markets by Howard Chong and David Sunding [41] warned that the frequency of transactions cannot be used as the sole indicator of water market success. In the case of LTSCs, we define LTSC transactions as successful when they allow buyers to obtain the amount of LTSCs they seek, and sellers to get the cash amount they need.

More recent articles present water markets as institutional arrangements [3,50,51]. They assume the existence of an entity that organizes sales and sets the transaction price. In Arizona, ADWR provides a central authority for quantifying LTSCs, maintaining transaction records, and ensuring compliance with Arizona's statutes, but does not organize sales or dictate prices.

Demand for water reallocation to those who value it most highly $[40,52,53]$ is an incentive for the development of markets in general. As early as 1984, Ingram et al. predicted an increase in water transactions to reallocate water to different users, stating that " $(\mathrm{w})$ hile markets for water rights are only beginning to appear in the United States, the reallocation of water by water sales and exchanges is on the rise and can be expected to play a more important role in water management in the future (p. 331)." In general, water markets have emerged as an alternative to other reallocation mechanisms where the competition for water is escalating [53]. Rights to the use of surface water flowing in Arizona are fully allocated, and transferring water rights is complex [43], consisting of a "series of procedural and regulatory requirements" (p. 13) [45]. In addition, very little CAP water remains to be allocated and priority use of unallocated water is controlled by CAWCD. Outside AMAs, water users without surface water rights can turn to groundwater; however, in AMAs groundwater users must have defined and quantified rights before they can pump groundwater. Thus, conditions exist within AMAs for development of a water market.

Water marketing can provide a financial incentive for groundwater right users to invest in water conservation in order make a profit on the unused water [43]. For example, in 2017, 74\% of Arizona's water demand came from agriculture [9]. A small reduction in the percentage of agricultural use would translate into a relatively large increase in water available for municipalities or industries. Such a market is likely to develop if legal and political barriers related to the sale of groundwater rights are removed [45].

Although LTSC transactions lack a price reference point, a key market function, these transactions effectuate reassignment of the right to use water through voluntary exchanges of value and therefore qualify as market-based activity. Very recently, an article by Landry et al. (p. 4) [54] characterized trades of "groundwater storage and recovery entitlements" of surface water and effluent as an "active 
market" in Arizona. This statement clearly refers to LTSC transactions and establishes the value of an in-depth examination of the existing record.

\section{Research Contribution}

Scholars have described the advantages of LTSCs as part of the Arizona Water Banking Authority (AWBA) and the Underground Water Storage, Savings and Replenishment Act in Arizona [1,55]. LTSCs are also mentioned when referring to groundwater management and sustainability in the Tucson basin [56], the innovative strategies of Arizona's water management by the AWBA, ADWR and CAWCD [57] and its recharge and recovery framework [28].

Outside of academia, one study by a consulting firm discussed LTSCs in a market context, calling LTSC transaction the most developed market for water in Arizona [58]. WestWater Research [59] published an accounting of the volumes of LTSC acquired by buyer type from 2008 to 2014. The Journal of Water, an online-based journal from the consulting firm Stratecon Inc., published very select data on recent LTSC transactions [60-62]. This paper is the first comprehensive examination of LTSC transactions and their contributions to multiple water management objectives. Market mechanisms of LTSC transactions may offer a useful approach to the water redistribution challenges of other water scarce regions.

\section{Materials and Methods}

Because, at the time of this writing, LTSC summaries for the years 2017, 2018 and 2019 were not available, the Materials and Methods Section will only determine the major participants involved in LTSC market-based transactions from 1994 to 2016. Nevertheless, more recent transactions, those publicly available directly from the major participants, are presented in the Results Section on a case by case basis.

\subsection{Development of Long-Term Storage Credit Transaction Database}

Through 2016, 197 long-term storage accounts were registered in Central Arizona AMAs and 13.8 billion of $\mathrm{m}^{3}$ of water were stored and physically available through LTSCs [63]. Although the recovery of LTSCs is restricted to the AMA in which they were stored, there are no legal restrictions on who can buy LTSCs. LTSCs may be resold, retained in storage, recovered, or extinguished for replenishment. A transaction does not involve the physical exchange of water; instead, ADWR transfers LTSCs from the seller's account to the purchaser's account.

The ADWR has been keeping track of every LTSC generated since 1994, and completes a yearly summary of LTSCs for every entity that owns these credits. To create the transactions database, 2358 LTSC holder's summaries (23 years of documentation maintained by ADWR) were examined. Each LTSC holder's summary shows LTSCs accrued or bought and recovered or sold during the year. One section displays the LTSCs stored by the holder, while a second section shows the number of credits transferred to the long-term storage holder's account, the seller, and the date of the transfer. A third section details the credits transferred out of the LTSC holder's account. Every LTSC transfer is associated with a water storage permit and linked to a facility permit. Among the 2358 LTSC holders' summaries, only 578 transfers of LTSCs were identified and reported in the database. The database shows how many LTSCs were transferred every year from 1994 to 2016 and the name of the buyers and sellers associated with each transfer.

Owners of LTSCs were categorized by type of entity. In total, seven categories were created to reflect the different types of LTSC owners in Central Arizona AMAs (Table 1): governmental entities, municipal water providers, Native American tribes, Gila River Water Storage (GRWS), industries, investment firms, and others. Five categories apply to all three Central Arizona AMAs: governmental entities, municipal water providers, Native American Tribes, industries, and investment firms. The GRWS is a separate category in the Phoenix and Pinal AMAs because it is a unique partnership between the GRIC and the Salt River Project (a quasi-governmental water and power 
utility). In the Phoenix and Tucson AMAs, an additional category called "others" contains home building agencies such as Del Webb and William Lyon Homes, and golf courses. Entities in the "other" category owned only $0.2 \%$ of the total LTSC in the Phoenix AMA, and $1.4 \%$ in the Tucson AMA as of 2016 (Table 1).

Table 1. Long-term storage credits owned by category in 2016 in Central Arizona Active Management Areas (AMAs). Data source: [63].

\begin{tabular}{ccccc}
\hline Category & Phoenix AMA & Tucson AMA & Pinal AMA & $\begin{array}{c}\text { Central Arizona } \\
\text { AMAs }\end{array}$ \\
\hline Governmental Entities & $43.0 \%$ & $61.0 \%$ & $66.4 \%$ & $51.4 \%$ \\
Municipal Water Providers & $36.3 \%$ & $26.8 \%$ & $3.0 \%$ & $26.8 \%$ \\
Industries & $6.4 \%$ & $2.6 \%$ & $3.3 \%$ & $5.1 \%$ \\
Native American Tribes & $5.6 \%$ & $7.0 \%$ & $7.9 \%$ & $6.4 \%$ \\
Gila River Water Storage & $2.1 \%$ & $0.0 \%$ & $19.3 \%$ & $5.9 \%$ \\
Investment Firms & $6.3 \%$ & $1.2 \%$ & $0.2 \%$ & $4.0 \%$ \\
Others & $0.2 \%$ & $1.4 \%$ & $0.0 \%$ & $0.4 \%$ \\
\hline
\end{tabular}

Governmental entities include CAWCD, AWBA, and the US Bureau of Reclamation. Municipal water providers include cities, towns, and private water providers that operate community water systems. Four Native American tribes have entered into LTSC transactions: the Gila River Indian Community (GRIC), Ak-Chin Indian Community, Pascua Yaqui Tribe, and Tohono O'odham Nation. Entities listed under the label "industries" are mining and power companies. The investment firm category includes Vidler Water Company (a private-sector water resource company), Aqua Capital Management, LP (a water right investment and management company), Fidelity National Title (an insurance company), Rocking K Acquisition, LLC (a real estate development and investment company), Mojave Ventures, LLC (an investment company).

\subsection{Selection of Transactions}

The first step of the analysis of LTSC transactions consisted of determining which transfers of LTSCs between ADWR accounts qualify as market-based transactions. In its LTSC holders' summaries, the ADWR refers to the shift of LTSCs between accounts as "transfers." In this analysis, monetary transfers-or transactions-were distinguished from non-monetary transfers. If a transfer of LTSCs occurred between accounts of the same entity, it was considered non-monetary, such as transfers among the multiple accounts held by CAWCD or AWBA. Additionally, LTSC transfers involving the Pinal County Water Augmentation Authority, and transfers between the GRWS and GRIC were considered non-monetary because no money changed hands. The GRIC owned the majority of Native American tribes' LTSCs in 2016 (100\% in the Pinal AMA, and 52\% in the Phoenix AMA). The GRIC partnered with the Salt River Project in 2010 to create the Gila River Water Storage, LLC to secure water supply for any prospective water users [64]. Together, they owned 12.3\% of LTSCs in Central Arizona AMAs in 2016 (Table 1). While the partnership sold 38,677 LTSCs through the GRWS account (mostly to Resolution Copper Mining), the GRIC and the GRWS have exchanged LTSCs twenty-three times between 2012 and 2016, for a total of 873,537 LTSCs. The GRWS may become an increasingly important player in LTSC transactions. In fact, in 2019 the GRWS, LLC sold to CAWCD for replenishment purposes 375,000 LTSCs in the Pinal AMA and 70,375 in the Phoenix AMA [65]. The GRWS advertises itself as "the largest holder of LTSCs available for purchase by municipal water providers, residential developers, and industrial water users" and as an alternative to CAGRD membership [64].

All other LTSC transfers were considered transactions of LTSCs. The ADWR does not require buyers and sellers to disclose the price of LTSCs and those data are generally unavailable, except for the CAWCD and the AWBA purchases. However, when LTSCs are transferred between accounts of different entities, money transfers are presumed because LTSCs have monetary value [60-62,65]. In Central Arizona AMAs between 1994 and 2016, non-monetary LTSC transfers involved 1,526,842 
LTSCs and LTSC transactions involved 927,293 LTSCs. Most LTSC transfers have been monetary in the Phoenix (55\%) and Tucson (84\%) AMAs, while only $8.7 \%$ of transfers in the Pinal AMA were monetary (Table 2). Non-monetary transfers of LTSCs were not part of this analysis and will not be discussed in the remainder of the article.

Table 2. Number of transfers and volume of Arizona's long-term storage credit transfers, from 1994 to 2016.

\begin{tabular}{ccccccc}
\hline Type of Transfers & \multicolumn{2}{c}{ Phoenix AMA } & \multicolumn{2}{c}{ Tucson AMA } & \multicolumn{2}{c}{ Pinal AMA } \\
\hline Total Transfers & 336 & 975,129 & 171 & 341,296 & 71 & $1,137,692$ \\
\hline Monetary Transfers (Sum) & 297 & 537,293 & 146 & 291,256 & 13 & 98,744 \\
\hline Non-Monetary Transfers (Sum) & 39 & 437,836 & 25 & 50,040 & 58 & $1,038,948$ \\
Central Arizona Groundwater & 27 & 82,922 & 22 & 15,938 & 14 & 17,769 \\
$\quad$ Replenishment District & 2 & 176,626 & 3 & 34,102 & 4 & 273,251 \\
Arizona Water Banking Authority & 10 & 178,288 & 0 & 0 & 13 & 695,249 \\
$\quad$ Gila River Water Storage & & & & & 27 & 52,679 \\
Pinal County Water Augmentation & & & & & &
\end{tabular}

\subsection{Selection of Major Participants}

The analysis focused on the categories of entities that were most active based on quantity of LTSCs bought and sold. In each AMA, major participant categories traded more LTSCs than would have been traded if all of the categories participated equally. For example, if the seven categories in the Phoenix AMA had participated equally in the sale and purchase of 537,293 LTSCs, they would each have traded 76,756 LTSCs (537,293 LTSCs/7 categories). Therefore, major participant categories in the Phoenix AMA either purchased or sold more than 76,756 LTSCs.

Based on this qualifying formula, municipal water providers, governmental entities, and investment firms are the major participants in the market-based transaction of LTSCs. In the Phoenix AMA, municipal water providers and investment firms qualify as main sellers, and governmental entities, investment firms, and municipal water providers qualify as major buyers. In the Tucson AMA, all three qualify as both as major buyers and sellers. Together, their activities represent $96 \%$ of purchases and $92 \%$ of sales. In the Pinal AMA, municipal water providers qualify as major sellers, and governmental entities qualify as both major sellers and buyers.

\section{Results}

\subsection{Transactions by Category of Participants}

This section provides the details of transactions between the sellers and buyers. Tables $3-5$ present the number and volume of LTSC transactions in the Phoenix, Tucson, and Pinal AMAs, respectively, by all participants. 
Table 3. Volume of Arizona long-term storage credit transactions in the Phoenix AMA, from seller to buyer, from 1994 to 2016.

\begin{tabular}{|c|c|c|c|c|c|c|c|c|}
\hline & & & & Buyer & & & & \\
\hline Seller & $\begin{array}{l}\text { Governmental } \\
\text { Entities }\end{array}$ & $\begin{array}{c}\text { Gila River } \\
\text { Water Storage }\end{array}$ & $\begin{array}{c}\text { Municipal } \\
\text { Water } \\
\text { Providers }\end{array}$ & $\begin{array}{l}\text { Native } \\
\text { American } \\
\text { Tribes }\end{array}$ & Industries & $\begin{array}{l}\text { Investment } \\
\quad \text { Firms }\end{array}$ & Others & Total \\
\hline Governmental Entities & 950 & 0 & 32,038 & 0 & 0 & 0 & 1320 & 34,308 \\
\hline $\begin{array}{l}\text { Gila River Water } \\
\text { Storage }\end{array}$ & 0 & 0 & 553 & 0 & 33,830 & 0 & 1294 & 35,677 \\
\hline $\begin{array}{l}\text { Municipal Water } \\
\text { Providers }\end{array}$ & 88,097 & 0 & 30,914 & 0 & 3033 & 97,989 & 43,511 & 263,546 \\
\hline Industries & 0 & 0 & 0 & 0 & 0 & 0 & 0 & 0 \\
\hline Investment Firms & 92,933 & 0 & 2642 & 0 & 9500 & 32,495 & 2277 & 139,847 \\
\hline Others & 12,167 & 0 & 27,638 & 1276 & 0 & 13,630 & 9203 & 63,914 \\
\hline Total & 194,147 & 0 & 93,785 & 1276 & 46,363 & 144,115 & 57,605 & 537,293 \\
\hline
\end{tabular}

Table 4. Volume of Arizona long-term storage credit transactions in the Tucson AMA, from seller to buyer, from 1994 to 2016.

\begin{tabular}{|c|c|c|c|c|c|c|c|}
\hline \multirow[b]{2}{*}{ Seller } & \multicolumn{7}{|c|}{ Buyer } \\
\hline & $\begin{array}{l}\text { Governmental } \\
\text { Entities }\end{array}$ & $\begin{array}{c}\text { Municipal Water } \\
\text { Providers }\end{array}$ & $\begin{array}{c}\text { Native American } \\
\text { Tribes }\end{array}$ & Industries & $\begin{array}{l}\text { Investment } \\
\text { Firms }\end{array}$ & Others & Total \\
\hline $\begin{array}{l}\text { Governmental } \\
\text { Entities }\end{array}$ & 60,000 & 8497 & 0 & 0 & 0 & 3500 & 71,997 \\
\hline $\begin{array}{l}\text { Municipal Water } \\
\text { Providers }\end{array}$ & 67,997 & 13,081 & 5000 & 2715 & 39,956 & 5383 & 134,133 \\
\hline $\begin{array}{c}\text { Native American } \\
\text { Tribes }\end{array}$ & 3899 & 0 & 0 & 0 & 0 & 0 & 3899 \\
\hline Industries & 0 & 0 & 0 & 0 & 0 & 0 & 0 \\
\hline Investment Firms & 22,032 & 2850 & 0 & 0 & 49,244 & 0 & 74,126 \\
\hline Others & 0 & 1001 & 0 & 0 & 0 & 6100 & 7101 \\
\hline Total & 153,928 & 25,429 & 5000 & 2715 & 89,200 & 14,983 & 291,256 \\
\hline
\end{tabular}

Table 5. Volume of Arizona long-term storage credit transactions in the Pinal AMA, from seller to buyer, from 1994 to 2016.

\begin{tabular}{|c|c|c|c|c|c|c|c|}
\hline \multirow[b]{2}{*}{ Seller } & \multicolumn{7}{|c|}{ Buyer } \\
\hline & $\begin{array}{l}\text { Governmental } \\
\text { Entities }\end{array}$ & $\begin{array}{c}\text { Gila River } \\
\text { Water Storage }\end{array}$ & $\begin{array}{c}\text { Municipal } \\
\text { Water Providers }\end{array}$ & $\begin{array}{c}\text { Native } \\
\text { American } \\
\text { Tribes }\end{array}$ & Industries & $\begin{array}{l}\text { Investment } \\
\text { Firms }\end{array}$ & Total \\
\hline $\begin{array}{l}\text { Governmental } \\
\text { Entities }\end{array}$ & 70,000 & 0 & 20,522 & 0 & 0 & 0 & 90,522 \\
\hline $\begin{array}{c}\text { Gila River Water } \\
\text { Storage }\end{array}$ & 0 & 0 & 3000 & 0 & 0 & 0 & 3000 \\
\hline $\begin{array}{l}\text { Municipal Water } \\
\text { Providers }\end{array}$ & 0 & 0 & 100 & 0 & 0 & 91 & 191 \\
\hline $\begin{array}{c}\text { Native American } \\
\text { Tribes }\end{array}$ & 0 & 0 & 0 & 0 & 5000 & 32 & 5032 \\
\hline Industries & 0 & 0 & 0 & 0 & 0 & 0 & 0 \\
\hline Investment Firms & 0 & 0 & 0 & 0 & 0 & 0 & 0 \\
\hline Total & 70,000 & 0 & 23,622 & 0 & 5000 & 122 & 98,744 \\
\hline
\end{tabular}

\subsection{Transactions by Major Participants}

\subsubsection{Governmental Entities}

Three governmental entities have been active in selling and buying LTSCs: Central Arizona Groundwater Replenishment District/CAWCD, AWBA, and US Bureau of Reclamation.

The CAGRD is an entity that replenishes groundwater on behalf of its members. LTSCs accumulated by the CAGRD will be extinguished for replenishment purposes. CAGRD has been actively purchasing LTSCs from municipal water providers and investment firms in both the Tucson and Phoenix AMAs.

Created in 1996, the AWBA stores Colorado River water to ensure that Arizona's CAP subcontractors and specified others have a stock of water if and when a shortage is declared on 
the river, a process called firming [28]. In essence, the AWBA stores CAP water to protect holders of municipal and industrial subcontracts during times of shortage and to facilitate Indian water rights settlements. Effective 24 July 2014, Arizona Revised Statutes 45-2423 [66] allow the AWBA to supplement storage so that it can meet its future firming obligations and responsibilities. The AWBA purchased 14,570 LTSCs from the City of Tucson in 2015 and 50,000 LTSCs from the investment firm Active Resources Management (now called Vidler Water Company) in the Phoenix AMA in 2016. According the AWBA 2017 Annual Report, the AWBA purchased 71,652 LTSCs at a cost of \$14 million for municipal and industrial CAP firming in Maricopa County, most of which (59,082 LTSCs) were located in the Phoenix AMA [67]. The AWBA purchased 12,570 LTSCs at a cost of just over $\$ 17.35$ million for municipal and industrial CAP firming in Pima County, all of which were located in the Tucson AMA [67]. The AWBA did not purchase LTSCs in the Pinal AMA.

\subsubsection{Municipal Water Providers}

In the Phoenix and Tucson AMAs, municipal water providers have sold more LTSCs than they purchased. In the Phoenix AMA, municipal water providers sold 2.8 times more LTSCs than they purchased. Goodyear, Scottsdale, and Liberty Utilities sold 42,928, 14,904, and 14,177 LTSCs respectively between 2006 and 2016. In the Tucson AMA, municipal water providers sold five times more LTSCs than they purchased. Between 2003 and 2016, the City of Tucson, the Metropolitan Domestic Water Improvement District (MDWID), the Town of Oro Valley, and the Town of Marana sold 29,570, 14,000, 13,407, and 3763 LTSCs respectively. Most LTSC sales by these municipal providers were to CAGRD.

\subsubsection{Investment Firms}

Anyone, anywhere may purchase LTSCs; consequently, this market is open to private firms. Investment firms are active in the trade of LTSCs in the Phoenix and Tucson AMAs. Since 2009, important trades have occurred between the Water Utility of Greater Tonopah, investment firms (Aqua Capital Management, LP, and Mojave Ventures, LLC), and CAGRD. The Water Utility of Greater Tonopah has been storing CAP water in a USF since 2007, the year it acquired a CAP water subcontract of $78,938 \mathrm{~m}^{3}$ per year. Most of the stored water, however, was water purchased annually from the pool of CAP water considered "excess" because it is not allocated by subcontract or CAWCD policy. The Water Utility of Greater Tonopah sold LTSCs to Mojave Ventures, LLC (21,558 in 2009; 23,427 in 2010 and 2012), and to Aqua Capital Management LP (29,271 in 2009). Aqua Capital Management then sold 27,087 LTSCs to Mojave Ventures, LLC in 2011, which also bought 4713 LTSCs in 2013 from Hassayampa Ventures, LLC. Mojave Ventures then sold 14,311 LTSCs to CAGRD between 2014 and 2016. Another important transaction was the sale of 50,000 LTSCs by Vidler Water Company (Active Resource Management) to AWBA. Vidler Water Company, a "self-described water-resource company owned by NASDAQ-traded PICO Holdings" [68] has been storing CAP water since 1998 at their recharge project in Harquahala Valley, directly west of Phoenix.

In the Tucson AMA, important trades have occurred since 1998 between Spanish Trail Water Company, three investment firms (Fidelity National Title/Trust \#10773, Rocking K Acquisitions, and Mojave Ventures LLC), and CAGRD. Spanish Trail Water Company has been accruing LTSCs since 1997 at groundwater saving facilities using excess CAP water. In 2007, it was awarded a CAP subcontract for 3,745,836 $\mathrm{m}^{3}$ of water per year. Fidelity National Title/Trust \#10773 purchased 6838 LTSCs in 1998 from Spanish Trail Water Company, then 20,000 in 2004. Rocking K acquisitions purchased 9668 LTSCs in 2008 from Spanish Trail Water Company, then an additional 1700 in 2010. Thus, over the study period Spanish Trail Water Company sold over 38,000 LTSCs to investment companies.

In 2009, Fidelity National Title/Trust \#10,773 sold 20,938 LTSCs to Rocking K Acquisitions, which sold 26,606 LTSCs to Mojave Ventures LLC in the same year, and 1700 in 2010. Mojave Ventures LLC sold 4044 LTSCs in 2014-2016 to CAGRD and Fidelity National Title/Trust \#10773 sold CAGRD 9900 LTSCs. 


\section{Discussion}

\subsection{Benefits of LTSC Transactions to Major Participants}

LTSCs are attractive because owners of LTSCs can use them to demonstrate an AWS for which developers and municipal water providers have to show compliance with the AMA's management goal. Possession of LTSCs also helps developers and municipal water providers demonstrate physical water availability when their LTSCs are located within the area of impact of the storage project. Physical availability can be demonstrated using LTSCs, whether those credits exist at the date of the application or the applicant proves it has the means to store water to generate LTSCs. In addition, municipal water providers that accumulate LTSCs in excess of their needs to withdraw renewable water from the aquifer may sell them to meet other needs, such as infrastructure expansion.

Governmental entities participate in market-based transactions of long-term storage credits to fulfill their statutory obligations. CAGRD may either add water to the aquifer or extinguish LTSCs to fulfil its replenishment obligation. CAGRD's annual replenishment obligation is projected to increase by $63 \%$ in 2034 [69] and keep increasing as members pump more excess groundwater. By law CAGRD may not refuse to accept new members, and its replenishment obligation will increase as new entities join. Moreover, CAGRD's primary source of renewable water, excess CAP water, is not expected to be available in the near future, because of projected shortages on the Colorado River. Therefore, CAGRD must look for alternative sources of supplies.

CAGRD had already identified LTSCs as an additional water source in its portfolio in its 2004 Plan of Operation [70]. As of 2015, CAGRD owned 1,094,069 LTSCs [63]. From 1994 to 2015, CAGRD purchased 298,075 LTSCs in the Phoenix and Tucson AMAs, from investment firms and municipal water providers. As a result, 27\% $(298,075 / 1,094,069)$ of the total LTSCs owned by CAGRD were accrued through purchase. Some of these LTSCs have already been extinguished toward replenishment. CAGRD is planning on acquiring 335,982 LTSCs in the Phoenix AMA and 119,264 LTSCs in the Tucson AMA in the next 100 years [69], a much slower pace of than between 1994 and 2015.

Until 2014, AWBA accrued LTSCs though storage of excess CAP water. As of 2016, the AWBA had stored a total of 3,053,206 LTSCs in Central Arizona AMAs to firm the supplies for municipal and industrial subcontractors (1,694,189 in the Phoenix AMA, 729,547 in the Pinal AMA, and 629,470 in the Tucson AMA). However, the quantity of excess CAP water available to AWBA has been decreasing since 2010 [71], and with the probability of shortages on the Colorado River, may disappear altogether. Consequently, ABWA is likely to rely more on the purchase of LTSCs in the future.

\subsection{Evolution of Transactions in Central Arizona Active Management Areas}

In general, the most transactions occurred and the greatest quantity of LTSCs were traded in the Phoenix AMA. Total number (Figure 2) and volume of transaction (Figure 3), although highly variable has shown an increasing trend.

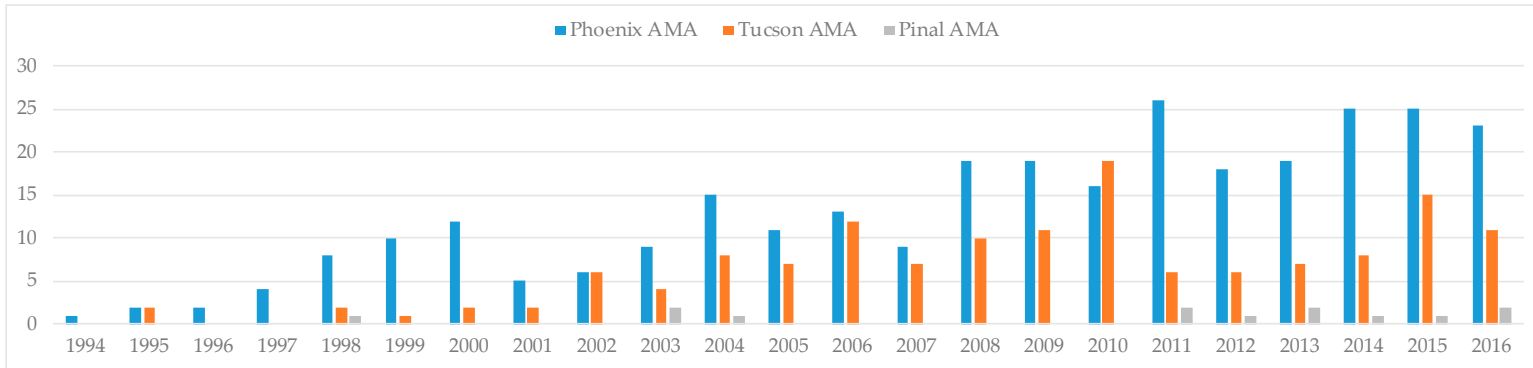

Figure 2. Number of long-term storage credits transactions in Central Arizona AMAs, from 1994 to 2016. 


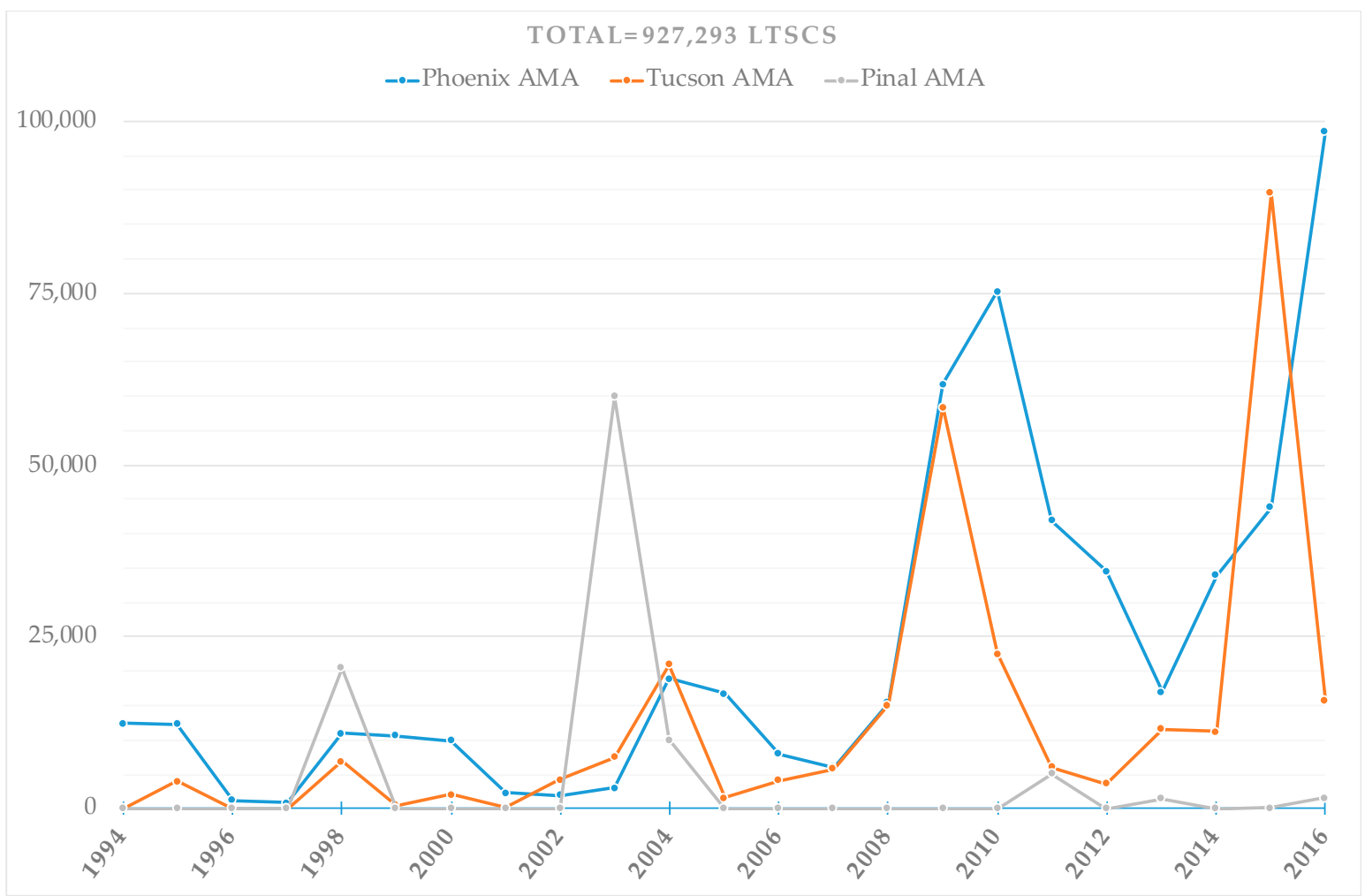

Figure 3. Volume of long-term storage credits sold in Central Arizona AMAs, from 1994 to 2016.

The Phoenix and Tucson AMAs have seen the quantity of LTSCs traded grow since 1994 (Figure 3). In 2009, transactions rose sharply in the Tucson and Phoenix AMAs, when several investment firms and the Water Utility of Greater Tonopah joined the market for the first time. The Tonopah utility and the City of Goodyear were the selling entities responsible for the 2010 peak in transactions in the Phoenix AMA. In 2015 in the Tucson AMA, the US Bureau of Reclamation sold 50,000 LTSCs to CAGRD to generate revenue to pay for delivery of CAP water to the Tohono $\mathrm{O}^{\prime}$ odham Nation as specified under the Southern Arizona Water Settlement Act of 1982, amended by title III of the 2004 Arizona Water Settlement Act [55]. The US Bureau of Reclamation had accrued the LTSCs through storage of City of Tucson effluent in the Santa Cruz River Managed USF in the Tucson AMA [72]. The 2016 peak in the Phoenix AMA was due to sales by investment firms to AWBA and CAGRD. In the Pinal AMA, as much as $92 \%$ of the LTSCs sales occurred before 2004, with a peak in 2003 (Figure 3) when CAWCD sold 50,000 LTSCs to AWBA.

\subsection{Triangular Pattern among Governmental Entities, Municipal Water Providers, and Investment Firms}

In both the Phoenix and Tucson AMAs, investment firms appear to have placed themselves between municipal water providers and governmental entities as LTSC brokers for some, but not all transactions. This is especially highlighted in Phoenix AMA, in which governmental agencies purchased $48 \%$ of their LTSCs from investment firms, while these firms purchased $68 \%$ of their LTSCs from municipal water providers (Table 3). For example, Aqua Capital Management and Mojave Ventures, whereby LLC appeared to act as intermediaries in the ultimate sale of LTSCs accrued by the Water Utility of Greater Tonopah to CAGRD (Figure 4). Similarly, the Spanish Trail Water Company was at the origin of transactions involving Rocking K Acquisitions, Fidelity National Title/Trust \#10773 and Mojave Ventures in the sale of LTSCs to CAGRD (Figure 5). 


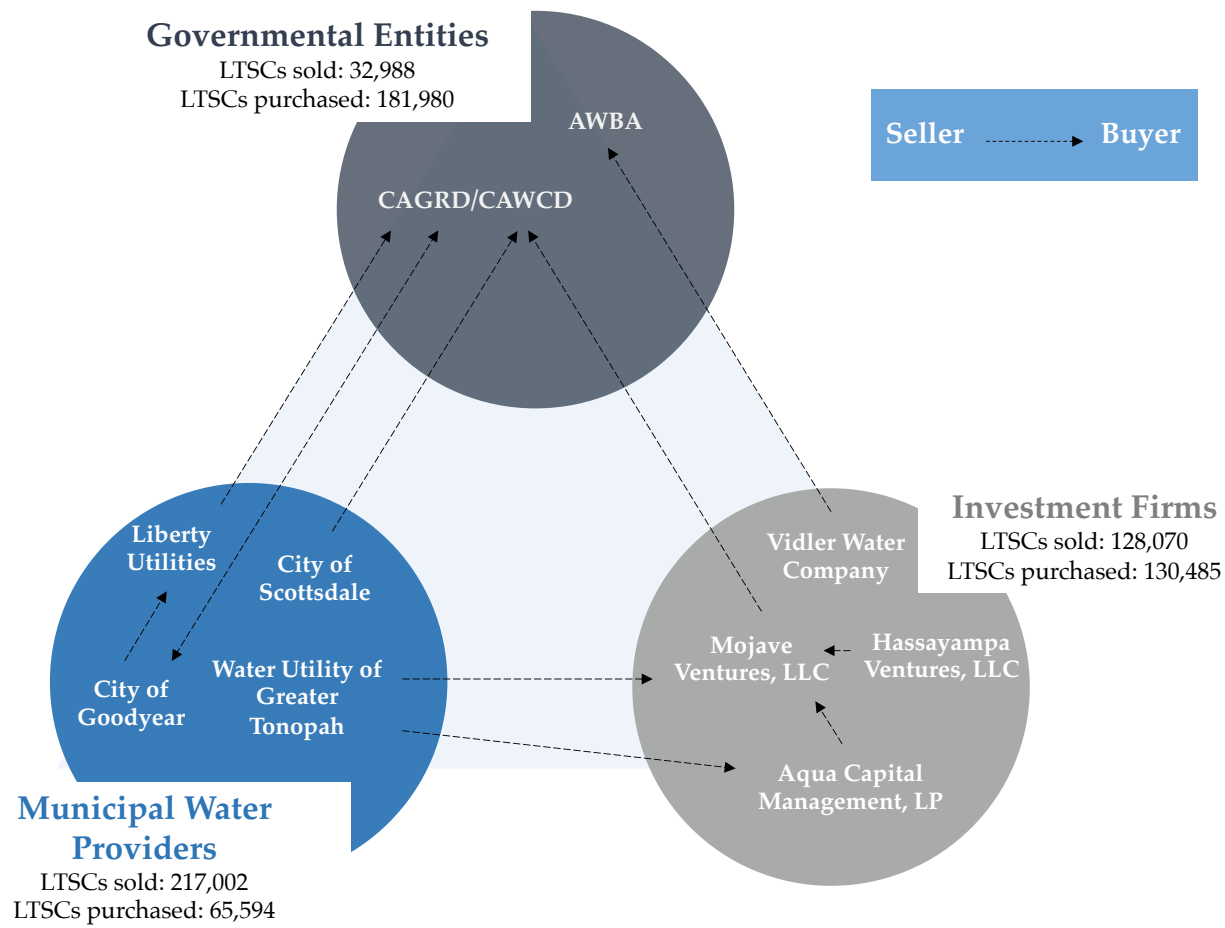

Figure 4. Direction of sales and purchases, and amount of long-term storage credits traded between governmental entities, municipal water providers, and investment firms, from 1994 to 2016 in the Phoenix AMA.

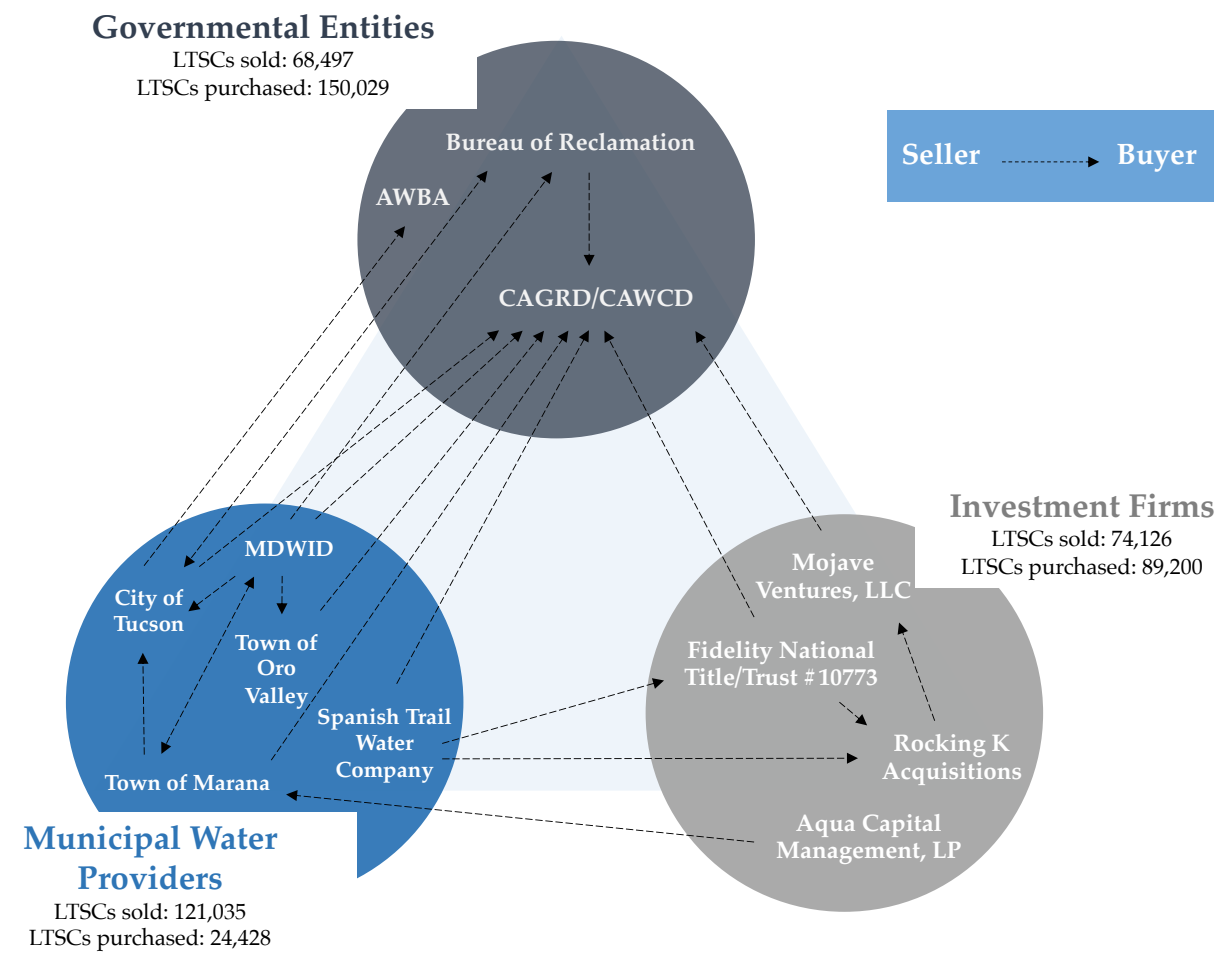

Figure 5. Direction of sales and purchases, and amount of long-term storage credits traded between governmental entities, municipal water providers, and investment firms, from 1994 to 2016 in the Tucson AMA. 
Nevertheless, in the Phoenix AMA, government entities purchased nearly as many LTSCs from investment firms than directly from municipal water providers. In fact, in the Tucson AMA, government agencies purchased more LTSCs from municipal water providers than from investment firms. In the Tucson AMA, investment firms mostly purchased LTSCs from one another. In addition, sales to municipal providers from investment firms were relatively rare in both AMAs. As for sales to investment firms from governmental agencies, they were non-existent in this case. Consequently, investment firms are clearly in the business of selling LTSCs to governmental agencies specifically.

In general, the majority of entities involved in LTSC trades from 1994 to 2016 owned the most LTSCs in 2016. In the Phoenix AMA, the investment firms that have been involved in trades are the ones that owned all of the LTSCs of their category. In the Tucson AMA, every investment firm that owned LTSCs has been involved in LTSCs transactions. This standard applies to municipal water providers in the Tucson AMA, in which the City of Tucson and the MDWID had the largest amount of LTSCs ( $83 \%$ of the total LTSCs owned by municipal water providers), and have been trading many LTSCs as shown in Figure 5. However in the Phoenix AMA, the four municipal water providers (the City of Mesa, City of Chandler, Town of Gilbert, and the City of Phoenix) that owned the most LTSCs in 2016 (61\% of the total LTSCs owned by municipal water providers) have not, or have barely been active in market-based transactions. Such arrangements suggest the need for additional research focused on the correlation between the amount of LTSCs owned over the years and the amount of LTSCs traded by each entity, in each AMA, and the way in which these entities perceive the benefits of LTSC transactions.

\section{Conclusions}

Based on more than 20 years of data, this paper presents who is trading LTSCs in three Central Arizona AMAs. Water users such as governmental entities, municipal water providers, and investment firms have participated in LTSC transactions. In this way, the article contributes not only to an understanding of Arizona water policy, but also to the literature on water markets. While this paper is narrow in its empirical scope, it opens up several areas for future research. For example, it would be useful for scholars and practitioners to develop comparative research on the variety of emerging water markets and market mechanisms around the world, of which LTSCs is one. Additionally, research into the organizations that specifically develop and participate in water markets should continue. In light of growing interest in effluent reuse and concerns about water contaminants, more research is needed to understand how water market mechanisms can account for the water quality issues surrounding recharge and recovery of CAP water and effluent.

Specifically, this article addressed how market-based transaction of LTSCs help participants meet their legal obligations. The CAGRD and AWBA have replenishment and firming responsibilities respectively, which they intend to meet partly through the purchase of LTSCs. In 2014, Arizona's legislature amended Arizona Revised Statutes 45-2423 to allow the AWBA to purchase existing LTSCs. This has been an important development in the history of LTSCs in Arizona. The fact that CAGRD and AWBA have been actively involved in market-based transactions of LTSCs demonstrates the importance of LTSCs for meeting Arizona's water management and policy goals. LTSCs may help municipal water providers or developers in AMAs comply with the AWS Rules, including compliance with AMA goals and management plans and, in some cases, may help demonstrate physical availability. The ability to purchase LTSCs is useful for municipal water providers or developers that do not have access to renewable water.

The experience with LTSCs in Arizona indicates that market mechanisms of transactions can be useful in regions that need to facilitate economic growth despite water scarcity. Future comparative research on water markets should evaluate different market mechanisms. Nevertheless, under Arizona law, LTSCs are much easier to acquire than surface water rights or Colorado River allocations. The LTSC model of water marketing could be applicable in areas in which aquifer storage is already developed with appropriate contextual considerations. First, buyers should have the assurance that they will 
be able to recover the stored water. This issue is particularly apparent in Arizona, where there is a distinction between "wet water" and "paper water." Defined in the context of water rights, "wet water" is physically available to the rights owner while "paper rights" are not, either because the water source was over-allocated or because other users are depleting the source [73]. One the one hand, LTSCs can be considered "paper water" because owning LTSCs does not grant recovery. On the other hand, LTSCs are created when water is either physically stored in the ground (USF) or when groundwater is saved (GSF). Unlike "paper rights" LTSCs represent water present in the aquifer, as required by Arizona state law. In that sense, LTSC can also be defined as "wet water" because water is physically available in the aquifer.

Moreover, for the LTSC model to be implemented elsewhere, a source of water should be available for recharge. Effluent reuse presents advantages because it increases proportionally with demand. Arizona Supreme court case, Arizona Public Service Company vs John F. Long, made effluent a legal type of water in 1989 [74]. As a distinct legal category of water in Arizona, effluent, and LTSCs of effluent, have become a commodity that may be traded. In Central Arizona AMAs, transactions of LTSCs were dominated by sales of CAP water from 1994 to 2016. In the Phoenix AMA, sales of LTSC effluent started slowly but steadily to increase in 2003. Moreover, in 2013 and 2015 sales of effluent dominated sales of LTSCs accrued with CAP storage in the Tucson AMA. Therefore, effluent has a clear role to play in the market-based transactions for LTSCs, and corresponds with one of the strategies of the AMAs, which is to replace groundwater with the reuse of effluent. A decrease in the availability of surface and groundwater in arid areas makes effluent an alternative resource. Nonetheless, in Arizona, LTSC transactions of CAP water are expected to continue because a large volume of CAP water already has been stored as LTSCs.

The Groundwater Management Act set the stage for a series of policies that Arizona has implemented to manage its water resources. Policy tools such as the AWS Rules, AWBA, and CAGRD established incentives for LTSC transactions. In addition, drought conditions in Arizona are making Colorado River water less reliable, and a declaration of shortage will reduce Arizona's Colorado River allocation. As a result, entities are accumulating LTSCs as a hedge against a shortage for Colorado River water. Thus, further increases in LTSC transactions are expected.

Author Contributions: Conceptualization, R.F.A.B. and S.B.M.; methodology, R.F.A.B.; formal analysis, R.F.A.B.; investigation, R.F.A.B.; writing-original draft preparation, R.F.A.B.; writing-review and editing, R.F.A.B., S.B.M. and S.E.; supervision, S.B.M. All authors have read and agreed to the published version of the manuscript.

Funding: This research received no external funding.

Acknowledgments: The authors would like to thank Mallory Orme, Water Resource Specialist, Arizona Department of Water Resources, for her assistance retrieving the long-term storage credit data necessary for this research.

Conflicts of Interest: The authors declare no conflict of interest.

\section{References}

1. Megdal, S.B.; Dillon, P.; Seasholes, K. Water Banks: Using Managed Aquifer Recharge to Meet Water Policy Objectives. Water 2014, 6, 1500-1514. [CrossRef]

2. Overpeck, J.T.; Cole, J.E. Abrupt Change in Earth's Climate System. Annu. Rev. Environ. Resour. 2006, 31, 1-31. [CrossRef]

3. Debaere, P.; Richter, B.D.; Davis, K.F.; Duvall, M.S.; Gephart, J.A.; O’Bannon, C.E.; Pelnik, C.; Powell, E.M.; Smith, T.W. Water markets as a response to scarcity. Water Policy 2014, 16, 625-649. [CrossRef]

4. ADWR Designation of Assured Water Supply (DWR. No. 86-402254.0001); Town of Marana: Marana, AZ, USA, 2018.

5. Glennon, R.; Culp, P. The Last Green Lagoon: How and Why the Bush Administration Should Save the Colorado River Delta. Ecol. Law Q. 2002, 28, 903. 
6. O'Neill, B.; Poupeau, F.; Coeurdray, M.; Cortinas Muñoz, J. The Law of the River: Conflict and coorperationon the Colorado River. In Water Bankruptcy in the Land of Plenty; CRC Press: Boca Raton, FL, USA, 2016; ISBN 978-1-4987-7699-8.

7. Kuhn, E.; Fleck, J. Science Be Damned: How Ignoring Inconvenient Science Drained the Colorado River; The University of Arizona Press: Tucson, AZ, USA, 2019; ISBN 978-0-8165-4005-1.

8. Arizona Town Hall Keeping Arizona's Water Glass Full. 2015. Available online: http://www.aztownhall. org/resources/Documents/107\%20Keeping\%20Arizona|T1 \textquoterights\%20Water\%20Glass\%20Full\% 20FINAL\%20Report\%20web.pdf (accessed on 23 October 2017).

9. ADWR Active Management Areas. Available online: https://new.azwater.gov/sites/default/files/media/ AMAFACTSHEET2016\%20\%281\%29_0.pdf (accessed on 3 July 2019).

10. U.S. Census Bureau. QuickFacts: Arizona. Available online: https://www.census.gov/quickfacts/fact/table/ az\# (accessed on 12 March 2019).

11. ADWR Phoenix AMA Historic Water Use Summary. Available online: https://infoshare.azwater.gov/ docushare/dsweb/ApplySimpleSearch (accessed on 24 January 2020).

12. ADWR Tucson AMA Historic Water Use Summary. Available online: https://infoshare.azwater.gov/ docushare/dsweb/ApplySimpleSearch (accessed on 24 January 2020).

13. ADWR Pinal AMA Historic Water Use Summary. Available online: https://infoshare.azwater.gov/docushare/ dsweb/ApplySimpleSearch (accessed on 24 January 2020).

14. Arizona State Legislature. Arizona Revised Statute 45-462; Arizona State Legislature Arizona. Available online: https://www.azleg.gov/viewdocument/?docName=https $\% 3 \mathrm{~A} \% 2 \mathrm{~F} \% 2 \mathrm{Fwww} \cdot a z l e g . g o v \% 2 \mathrm{Fars} \% 2 \mathrm{~F} 45 \%$ 2F00462.htm (accessed on 24 January 2020).

15. Arizona State Legislature. Arizona Revised Statute 45-491; Arizona State Legislature Arizona. Available online: https://www.azleg.gov/viewdocument/?docName=https\%3A\%2F\%2Fwww.azleg.gov\%2Fars\%2F45\% 2F00491.htm (accessed on 24 January 2020).

16. Arizona State Legislature. Arizona Revised Statute 45-464; Arizona State Legislature Arizona. Available online: https://www.azleg.gov/viewdocument/?docName=https $\% 3 \mathrm{~A} \% 2 \mathrm{~F} \% 2 \mathrm{Fwww} \cdot a z l e g . g o v \% 2 \mathrm{Fars} \% 2 \mathrm{~F} 45 \%$ 2F00464.htm (accessed on 3 February 2020).

17. Arizona State Legislature. Arizona Revised Statute 45-512; Arizona State Legislature Arizona. Available online: https://www.azleg.gov/viewdocument/?docName=https:/www.azleg.gov/ars/45/00512.htm (accessed on 24 January 2020).

18. Arizona State Legislature. Arizona Revised Statute 45-463; Arizona State Legislature Arizona. Available online: https://www.azleg.gov/viewdocument/?docName=https $\% 3 \mathrm{~A} \% 2 \mathrm{~F} \% 2 \mathrm{Fwww} \cdot$ azleg.gov $\% 2 \mathrm{Fars} \% 2 \mathrm{~F} 45 \%$ 2F00463.htm (accessed on 3 February 2020).

19. Arizona State Legislature. Arizona Revised Statute 45-454; Arizona State Legislature Arizona. Available online: https://www.azleg.gov/viewdocument/?docName=https://www.azleg.gov/ars/45/00454.htm (accessed on 24 January 2020).

20. Glennon, R. Water Scarcity, Marketing, and Privatization. Tex. Law Rev. Austin 2005, 83, 1873-1902.

21. Megdal, S.B. The role of the public and private sectors in water provision in Arizona, USA. Water Int. 2012, 37, 156-168. [CrossRef]

22. Megdal, S.B.; Smith, Z.A.; Lien, A.M. Evolution and Evaluation of the Active Management Area Management Plans; Water Resources Research Center, University of Arizona: Tucson, AZ, USA, 2008.

23. Arizona State Legislature. Arizona Revised Statute (A.R.S.) 45-562; Arizona State Legislature Arizona. Available online: https://www.azleg.gov/viewdocument/?docName=https://www.azleg.gov/ars/45/00562. htm (accessed on 17 December 2019).

24. Arizona State Legislature. Arizona Revised Statute (A.R.S.) 45-561; Arizona State Legislature Arizona. Available online: https://www.azleg.gov/viewdocument/?docName=https $\% 3 \mathrm{~A} \% 2 \mathrm{~F} \% 2 \mathrm{Fwww} \cdot$ azleg.gov $\%$ 2Fars\%2F45\%2F00561.htm (accessed on 17 December 2019).

25. Arizona Department of State; Office of the Secretary of State, Administrative Rules Division; Arizona Department of Water Resources. Arizona Administrative Code (A.A.C) R12-15-724; Arizona Department of State. Available online: https://apps.azsos.gov/public_services/Title_12/12-15.pdf (accessed on 17 December 2019).

26. Arizona Department of State; Office of the Secretary of State, Administrative Rules Division; Arizona Department of Water Resources. Arizona Administrative Code (A.A.C) R12-15-725; Arizona Department of State. Available online: https://apps.azsos.gov/public_services/Title_12/12-15.pdf (accessed on 17 December 2019). 
27. Arizona Department of State; Office of the Secretary of State, Administrative Rules Division; Arizona Department of Water Resources. Arizona Administrative Code (A.A.C) R12-15-727; Arizona Department of State. Available online: https:/apps.azsos.gov/public_services/Title_12/12-15.pdf (accessed on 17 December 2019).

28. Megdal, S.B. Arizona's Recharge and Recovery Programs. In Arizona Water Policy: Management Innovations in an Urbanizing, Arid Region; Resources for the Future: Washington, DC, USA, 2006; ISBN 978-1-936331-39-0.

29. Megdal, S.B.; Shipman, T.D. Arizona's Groundwater Savings Program; Southwest Hydrology; University of Arizona Water Resources Research Center: Tucson, AZ, USA, 2008.

30. Arizona State Legislature. Arizona Revised Statute (A.R.S.) 45-834.01; Arizona State Legislature. Available online: https://www.azleg.gov/viewdocument/?docName=https://www.azleg.gov/ars/45/00854-01.htm (accessed on 30 December 2019).

31. ADWR Phoenix AMA Third Active Management Plan. Available online: http://infoshare.azwater.gov/ docushare/dsweb/Get/Document-10007/PhoenixAMA_3MP.pdf (accessed on 30 December 2019).

32. ADWR Fourth Management Plan, Tucson Active Management Area. Available online: http://www.azwater.gov/ azdwr/WaterManagement/AMAs/documents/TAMA_COMPLETE_TitlepagethruChap12_NoSupplements. pdf (accessed on 22 October 2017).

33. ADWR Pinal AMA Third Management Plan. Available online: http://infoshare.azwater.gov/docushare/ dsweb/Get/Document-10005/PinalAMA_3MP.pdf (accessed on 30 December 2019).

34. Arizona State Legislature. Arizona Revised Statute (A.R.S.) 45-802.02; Arizona State Legislature. Available online: https://www.azleg.gov/viewdocument/?docName=https://www.azleg.gov/ars/45/00802-01.01.htm (accessed on 17 December 2019).

35. Ingram, H.M.; Mann, D.E.; Weatherford, G.D.; Cortner, H.J. Guidelines for Improved Institutional Analysis in Water Resources Planning. Water Resour. Res. 1984, 20, 323-334. [CrossRef]

36. Colby, B.; Bush, D.B. Water Markets in Theory and Practice. Market Transfers, Water Values, and Public Policy; Vol. Studies in Water Policy and Management; Westview Press: Boulder, CO, USA, 1987.

37. Colby, B.G. Enhancing instream flow benefits in an era of water marketing. Water Resour. Res. 1990, 26, 1113-1120. [CrossRef]

38. Water Transfers in the West: Efficiency, Equity, and The environment; National Research Council (U.S.), Ed.; National Academy Press: Washington, DC, USA, 1992; ISBN 978-0-309-04528-5.

39. Stewart, B.A.; Howell, T.A. Encyclopedia of Water Science; Marcel Dekker: New York, NY, USA, 2003; ISBN 978-0-8247-0948-8.

40. Brookshire, D.S.; Colby, B.; Ewers, M.; Ganderton, P.T. Market prices for water in the semiarid West of the United States. Water Resour. Res. 2004, 40. [CrossRef]

41. Chong, H.; Sunding, D. Water Markets and Trading. Annu. Rev. Environ. Resour. 2006, 31, 239-264. [CrossRef]

42. Grafton, R.Q.; Libecap, G.; McGlennon, S.; Landry, C.; O’Brien, B. An Integrated Assessment of Water Markets: A Cross-Country Comparison. Rev. Environ. Econ. Policy 2011, 5, 219-239. [CrossRef]

43. Thompson, B.H.; Leshy, J.D.; Abrams, R.H. Legal Control of Water Resources: Cases and Materials; West: St. Paul, MN, USA, 2013.

44. Garrick, D. Water Allocation in Rivers under Pressure: Water Trading, Transaction Costs and Transboundary Governance in the Western US and Australia; Edward Elgar Publishing: Cheltenham, UK, 2015; ISBN 978-1-78100-386-2.

45. Culp, P.; Glennon, R.; Libecap, G. Shopping for Water; Island Press/Center for Resource Economics: Washington, DC, USA, 2015; ISBN 978-1-59726-524-9.

46. Richter, B.D.; Brown, J.D.; DiBenedetto, R.; Gorsky, A.; Keenan, E.; Madray, C.; Morris, M.; Rowell, D.; Ryu, S. Opportunities for saving and reallocating agricultural water to alleviate water scarcity. Water Policy 2017, 19, 886-907. [CrossRef]

47. Julian, J.P.; Weaver, R.C. Demand for Stream Mitigation in Colorado, USA. Water 2019, 11, 174. [CrossRef]

48. Brown, T.C. Trends in water market activity and price in the western United States. Water Resour. Res. 2006, 42. [CrossRef]

49. Schwabe, K.; Nemati, M.; Landry, C.; Zimmerman, G. Water Markets in the Western United States and Opportunities. Water 2020, 12, 233. [CrossRef]

50. Theesfeld, I. Institutional Challenges for National Groundwater Governance: Policies and Issues. GroundWater 2010, 48, 131-142. [CrossRef] 
51. Breviglieri, G.V.; do Sol Osório, G.I.; Puppim de Oliveira, J.A. Understanding the emergence of water market institutions: Learning from functioning water markets in three countries. Water Policy 2018, 20, 1075-1091. [CrossRef]

52. Howe, C.W.; Schurmeier, D.R.; Shaw, W.D. Innovative Approaches to Water Allocation: The Potential for Water Markets. Water Resour. Res. 1986, 22, 439-445. [CrossRef]

53. Brookshire, D.S.; Ganderton, P.T. Introduction to special section on Water Markets and Banking: Institutional Evolution and Empirical Perspectives: INTRODUCTION. Water Resour. Res. 2004, 40. [CrossRef]

54. Landry, C.; Seely, H.; Payne, M.; Mennell, B.; Arnao, A. Water Rights Trading, Market Performance and Metrics of Water Rights Trading across the West. Water Rep. 2019, 183, 1-9.

55. Bark Rosalind, H.; Jacobs Katharine, L. Indian water rights settlements and water management innovations: The role of the Arizona Water Settlements Act. Water Resour. Res. 2009, 45. [CrossRef]

56. Cabello, V.; Hernández-Mora, N.; Serrat-Capdevilla, A.; Del Moral, L.; Curley, E.F. Implications of spacially neutral groundwater management: Water use and sustanability in the Tucson basin. In Water Bankruptcy in the Land of Plenty; CRC Press: Boca Raton, FL, USA, 2016; ISBN 978-1-4987-7699-8.

57. Zhao, C.; Wang, P.; Zhang, G. A comparison of integrated river basin management strategies: A global perspective. Phys. Chem. Earth 2015, 89-90, 10-17. [CrossRef]

58. Payne, M. Presentation: Arizona Water Market Update: Trends and Recent Developments. Available online: http://www.cap-az.com/documents/meetings/2018-08-16/1711-2-CommitteeWSPUpdate-8-2018-V4.pdf (accessed on 31 August 2018).

59. WestWater Research Central Arizona's Market for Long Term Storage Credits. Available online: https://www. waterexchange.com/wp-content/uploads/2014/09/FNAL-2_14-0905-WWInsider-6singles.pdf (accessed on 17 March 2019).

60. GRIC, City of Chandler Ink Deal to Meet City's Long-Term Water Needs. Available online: http:// journalofwater.com/jow/gric-city-of-chandler-ink-deal-to-meet-citys-long-term-water-needs/ (accessed on 20 March 2017).

61. CAWCD and AWBA Purchase Long-Term Storage Credits. Available online: http://journalofwater.com/jow/ cawcd-and-awba-purchase-long-term-storage-credits/ (accessed on 20 March 2017).

62. GRIC, Phoenix Enter Collaborative Agreements to Address Arizona's Long-Term Water Needs. Available online: http://journalofwater.com/jow/gric-phoenix-enter-collaborative-agreements-to-address-arizonaslong-term-water-needs/ (accessed on 20 August 2017).

63. Arizona Department of Water Resources Long-Term Storage Credit Account Summaries. Available online: http://infoshare.azwater.gov/docushare/dsweb/View/Collection-93 (accessed on 17 December 2019).

64. GRWS Salt River Project and Gila River Indian Community. Available online: https://www.gilawater.com/ about/grws.aspx (accessed on 5 May 2017).

65. Gila River Water Storage, LLC and Central Arizona Water Conservation District. Central Arizona Water Conservation District Purchase and Sale Agreement for Long-Term Storage Credits. 2019. Available online: http://cagrd.com/ documents/acquisitions/Gila-River-Water-Storage-Purchase-and-Sale-Agreements-for-LTSCs.pdf (accessed on 2 February 2020).

66. Arizona State Legislature. Arizona Revised Statute (A.R.S.) 45-2423; Arizona State Legislature. Available online: https://www.azleg.gov/viewdocument/?docName=https://www.azleg.gov/ars/45/02423.htm (accessed on 17 December 2019).

67. Arizona Water Banking Authority AWBA 2017 Annual Report. Available online: https://waterbank.az.gov/ sites/default/files/Final_AWBA_2017_Annual_Report.pdf (accessed on 3 June 2017).

68. Whitman, E. In Arizona, Private Companies Hope to Wring Profits From Drought. Phoenix New Times, 28 February 2019.

69. Central Arizona Groundwater Replenishment District CAGRD PLAN OF OPERATION. Available online: https://www.cagrd.com/documents/plan-of-operations/2015-CAGRD-Plan-of-Operation.pdf (accessed on 2 June 2019).

70. Central Arizona Groundwater Replenishment District CAGRD PLAN OF OPERATION. Available online: https://www.cagrd.com/documents/plan-of-operations/Plan-of-Operation.pdf (accessed on 13 April 2019).

71. Arizona Water Banking Authority AWBA Activities-Updates. Available online: http://www.azwaterbank. gov/Background/Updates.htm (accessed on 17 March 2019). 
72. CAWCD; Bureau of Reclamation Agreement between the United States and the Central Arizona Water Conservation District for the Sale and Purchase of Long-Term Storage Credits. Available online: http: //cagrd.com/documents/acquisitions/Final_signed_agmt_BOR_CAGRD.pdf (accessed on 21 November 2019).

73. Glennon, R. Water Follies: Groundwater Pumping and the Fate of America's Fresh Waters; Island Press: Washington, DC, USA, 2002.

74. Colby, B.G.; Smith, D.R.; Pittenger, K. Water Transactions Enhancing Supply Reliability during Drought. In Arizona Water Policy: Management Innovations in an Urbanizing, Arid Region; Routledge: London, UK, 2006.

(C) 2020 by the authors. Licensee MDPI, Basel, Switzerland. This article is an open access article distributed under the terms and conditions of the Creative Commons Attribution (CC BY) license (http://creativecommons.org/licenses/by/4.0/). 